\title{
Roles of the PI3K/AKT/mTOR signalling pathways in neurodegenerative diseases and tumours
}

Fei $\mathrm{Xu}^{1,2}$, Lixin $\mathrm{Na}^{2,3}$, Yanfei $\mathrm{Li}^{3}$ and Linjun Chen ${ }^{3^{*}}$

\section{Abstract}

The PI3 K/AKT/mTOR signalling pathway plays an important role in the regulation of s nal transy action and biological processes such as cell proliferation, apoptosis, metabolism and angiogenesis Con red with those of other signalling pathways, the components of the PI3K/AKT/mTOR signalling pathw/ay compl, ated. The regulatory mechanisms and biological functions of the PI3K/AKT/mTOR signalling path v z imnortant in many human diseases, including ischaemic brain injury, neurodegenerative diseases, and tumo PI3K/AKT/mTOR signalling pathway inhibitors include single-component and dual inhibitors. Numerous PI - inhibitol, have exhibited good results in preclinical studies, and some have been clinically tested in haematologic mallyn cies and solid tumours. In this review, we briefly summarize the results of research on the PI3K/AKT/mTOR path vay and discuss the structural composition, activation, communication processes, regulatory mechanisn biological functions of the PI3K/AKT/mTOR signalling pathway in the pathogenesis of neurodegenerative $\mathcal{L}_{\text {ases a }} d$ tumours.

Keywords: PI3K/AKT/mTOR signalling pathway, Regaadtory chanism, Ischaemic brain injury, Neurodegenerative diseases, Tumour

\section{Key points}

1. We summarize the PI3K/AK /mTOR, signalling pathway and its composition.

2. We list the current com nly PIJK/AKT/mTOR inhibitors for preclinical and $\mathrm{Cl}$. $M$ development.

3. We summarize the ent research progress regarding the PI3K/AK ' $\mathrm{mT}$ IR sig.lalling pathway in common human dises $\&$ (neurodegenerative diseases and tumo's

4. We aimed to rovide useful suggestions for addition a research, $n$ the mechanism underlying the bio ric $\mathrm{N}$ re rulation of this pathway.

*Co ondence: xf88_shanghai@163.com

${ }^{3}$ Depar nent of Inspection and Quarantine, Shanghai University of Medicine \& Health Sciences, Shanghai 201318, China

Full list of author information is available at the end of the article

\section{Introduction}

Multicellular organisms comprise an orderly and controllable collection of cells. The maintenance of such multicellular organisms depends on not only material and energy metabolism but also intercellular communication and signal regulation. In general, different communication signals regulate various life activities and cellular behaviours. PI3K/AKT/mTOR signalling constitutes an important pathway that consists of two parts: phosphatidylinositol 3-kinase (PI3K) and its downstream molecule serine/threonine protein kinase B (PKB; also known as AKT) $[1,2]$. The PI3K/AKT/ mTOR pathway is stimulated by RTK and cytokine receptor activation. Tyrosine residues are then phosphorylated and provide anchor sites for PI3K translocation to the membrane, thus participating in the transduction of various extracellular matrix molecules and cytokines [3-5]. This signalling pathway also has important biological effects on cells, such as improving

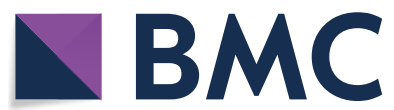

(c) The Author(s) 2020. This article is licensed under a Creative Commons Attribution 4.0 International License, which permits use, sharing, adaptation, distribution and reproduction in any medium or format, as long as you give appropriate credit to the original author(s) and the source, provide a link to the Creative Commons licence, and indicate if changes were made. The images or other third party material in this article are included in the article's Creative Commons licence, unless indicated otherwise in a credit line to the material. If material is not included in the article's Creative Commons licence and your intended use is not permitted by statutory regulation or exceeds the permitted use, you will need to obtain permission directly from the copyright holder. To view a copy of this licence, visit http://creativeco mmons.org/licenses/by/4.0/. The Creative Commons Public Domain Dedication waiver (http://creativecommons.org/publicdomain/ zero/1.0/) applies to the data made available in this article, unless otherwise stated in a credit line to the data. 
viability and inhibiting senescence, ageing and death $[2,6-8]$, and is associated with normal and abnormal physiological activity. Dysfunction of this pathway is related to not only the occurrence and development of tumours but also many other human diseases, such as leukaemia, diabetes, and schizophrenia [9-11]. Researchers have gradually gained a strong understanding of $\mathrm{PI} 3 \mathrm{~K} / \mathrm{AKT} / \mathrm{mTOR}$ signalling pathway regulation and function and agree that thoroughly elucidating the mechanism of PI3K/AKT/mTOR signal transmission and the related upstream and downstream molecules is necessary [12-14]. Such knowledge will help facilitate the use of this pathway as a target for treating tumours and other related diseases. However, because the structure and function of the PI3K/AKT/mTOR signalling pathway and its relationship with upstream and downstream molecules are complex, further research is needed for a complete understanding. This review aims to summarize the recent research progress on the PI3K/ AKT/mTOR signalling pathway in common human diseases (neurodegenerative diseases and tumours) and to provide a valuable reference for further research.

\section{The PI3K/AKT/mTOR signalling pathway and its composition}

The PI3K/AKT/mTOR signalling pathway consists of two parts: PI3K and its downstream molecule PKB/AKT [15] (Fig. 1).

\section{PI3Ks}

Phosphatidylinositol-3-kinases (PI3Ks) can be vided into three subtypes according to their structures an 15 strate specificities: class I, class II and III. Mmong these kinases, the most widely studizu are ss / PI3Ks, which can be activated directly y cell sur, ace receptors. Class I PI3Ks are further di led int class IA and IB based on their mode on tiva. Class IA PI3Ks are activated by RTK G $\mathrm{G}$ p in-coupled receptors and the small $\mathrm{G}$ protein $\mathrm{AS}$. Or the other hand, class IB PI3Ks, which consist of ly one subunit (PI3K $\gamma$ ), are activated by oniy $($ protein-coupled receptors. Class I PI3Ks are com $\mathrm{e}$ sulatory (p85 $\alpha, \mathrm{p} 85 \beta$ and $\mathrm{p} 85 \gamma)$ and catalytic (p1 p110, $\mathrm{p} 110 \delta$, and $\mathrm{p} 110 \gamma)$; among them, $\mathrm{p} 1$ and $\mathrm{p} 10 \beta$ are widely expressed in many tissues, whil $\mathrm{p}, 10 \delta$ and $\mathrm{p} 110 \gamma$ are mainly expressed

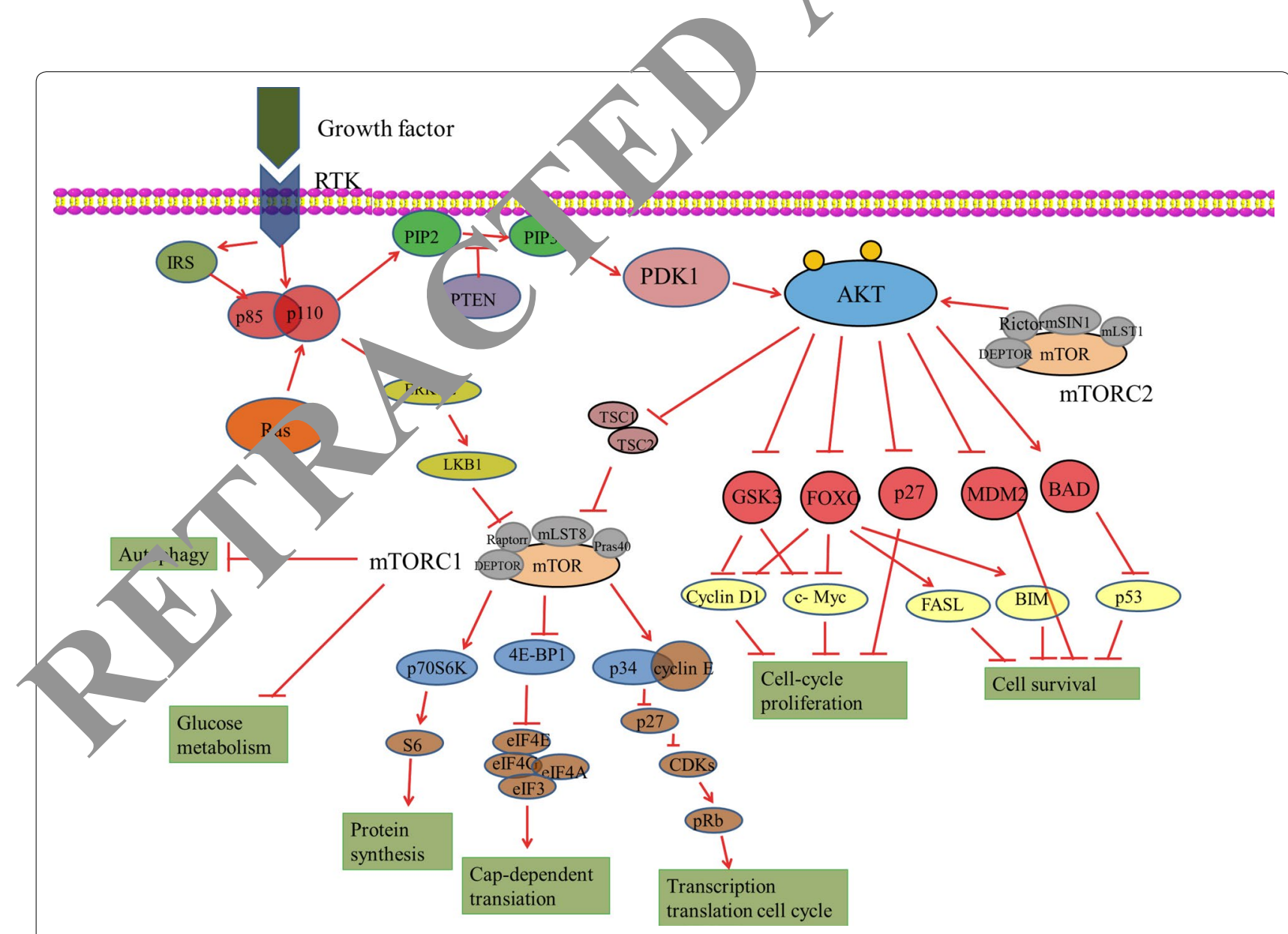

Fig. 1 Overview of the PI3K/AKT/mTOR signalling pathway 
in leukocytes [12, 16]. Activation by ligands, including growth factors, results in the tyrosine phosphorylation of cell surface receptors. The p85 regulatory subunit of class IA PI3Ks binds directly to tyrosine receptors on cell membranes activated by ligands such as platelet-like growth factor and receptor-associated proteins (such as IRS1). This binding consequently activates the p110 catalytic subunit, which catalyses the conversion of PIP2 to PIP3. As a second messenger, PIP3 regulates many downstream signalling pathways. Class IB PI3Ks are heterodimers consisting of the p101 regulatory subunit and the p110y catalytic subunit. Class IB PI3Ks are activated via the direct binding of p110y to the G $\beta \gamma$ subunit of G protein-coupled receptors $[15,17,18]$.

Although PI3Ks play an important role in cell growth, survival, differentiation, glucose transport and metabolism, the specific mechanisms of their subunits remain unknown. In general, the important roles of the p85 catalytic and p110 regulatory subunits of PI3Ks in regulating glycolipid metabolism have been revealed by gene knockout and other approaches. For example, p110 $\alpha-$ and p110 $\beta$-knockout mouse embryos die during early development, suggesting that these two subunits have an important function in embryonic development [19]. In addition, heterozygous $\mathrm{p} 110 \alpha \pm$ or $\mathrm{p} 110 \beta \pm$ mice do not exhibit decreased insulin sensitivity or obviously abnormal glucose metabolism. However, heterozygon nis ? with double knockout of these two genes she w sig. cantly impaired glucose tolerance, decreaser. ulin ser. sitivity and hyperinsulinaemia, suggesting that e two subunits play overlapping roles in th process of slycometabolism [20].

\section{AKT}

As the main molecule downstre $m$. PI $3 \mathrm{~K}$ signalling pathway, the serine/thr - ne protein kinase AKT comprises three subtype AK 1 AK T2 and AKT3, which are encoded by $P \wedge B \alpha, \quad B \beta$ and $P K B \gamma$, respectively [3, 21]. AKT1 is y $\mathrm{I}_{\mathrm{y}}$ expre, oed in many tissues, AKT2 is expressed in main insulin-sensitive tissues and at low levels in ther tissues, and AKT3 is expressed in only the brain an e...is. 'The specific tissue expression patterns of the "fere $4 \mathrm{~K} / \mathrm{T}$ ' subtypes suggest their key roles in the ain nance of physiological functions in different tissu or urgans $[22,23]$.

Th three AKT subtypes exhibit $85 \%$ amino acid sequence homology and very similar three-dimensional structures, which are composed of three different functional domains. The $\mathrm{N}$-terminal pleckstrin homology $(\mathrm{PH})$ domain regulates protein-protein and proteinlipid interactions. The central kinase catalytic domain is highly homologous with the regions of protein kinase A (PKA) and protein kinase $\mathrm{C}$ (PKC) that are responsible for enzymatic activity. Furthermore, phosphorylation of Thr308, located in this domain, is necessary for AKT activation. The regulatory region of the $\mathrm{C}$-terminal AKT domain contains Ser473, which is necessary for complete AKT activation [21, 24, 25].

AKT is regulated by a variety of hormones, inc $c^{1}$ ding insulin and growth factors [26]. As mention above, after the PI3K regulatory subunit binds to th orresponding receptors or receptor-binding protein o lae cell membrane, its catalytic subunit ctivat d and catalyses the formation of PIP3, writich n cecruits PDK1 and AKT to the cell membr ne [26, 27].

PDK1 is phosphorylated at Thr 8 in the AKT kinase catalytic region; PDK2 is the hos $_{\mathrm{P}}$ ylated at Ser473 in the regulatory region 121$]$. $k$ nt research has identified a series of pote it grin-linked kinase (ILK), DKC $\beta I I), ~ D N A-d e p e n d e n t$ protein kinase (DI -PK), anammalian target of rapamycin (mTOR, $\quad Z$ (mTORC2) and AKT [25, 28]. Activated AKT $\mathrm{n}$. iates the regulation of cell growth, proliferat the ceil cycle and glycometabolism by further phosphory, ating the GSK-3, FoxOs, Bad, Caspase 9. nuclear ranscription factor-kappa B (NF-kappa B), $\mathrm{m} . \mathrm{Z}$ and $\mathrm{p} 21$ proteins $[25,29]$.

\section{$T+$ Arget proteins}

FoxO1 The Forkhead family is a relatively new transcription factor family that was formally named in 2000 [30]. Since the discovery of the first Forkhead gene in Drosophila in 1989, more than 100 members of the family have been identified [31]. The common feature of the Forkhead family is a conserved DNA-binding domain called Fox, which consists of three $\alpha$-helices, three $\beta$-sheets and two loops that are referred to as wings [32, 33]. Because of this feature, these transcription factors are called Forkhead/ winged helix transcription factors. The Forkhead transcription factor family is currently divided into 17 subfamilies (named FoxA to FoxQ), the members of which have a wide range of biological functions [34, 35]. Among these subfamilies, the Forkhead box $\mathrm{O}$ (FoxO) family is the most thoroughly studied. Four distinct genes encode FoxO proteins in mammalian cells: FoxO1 (FKHR), FoxO3 (FKHRL1), FoxO4 (Afx) and FoxO6. The four homologous FoxO genes in humans are FoxO1, FoxO2, FoxO3a and FoxO4 [34]. FoxO functions in phosphorylation and acetylation posttranscriptional modifications at serine, threonine and lysine residues [35, 36]. Moreover, members of the FoxO subfamily shuttle from the cytoplasm to the nucleus and play an important role in cell proliferation, apoptosis, differentiation and oxidative stress resistance $[35,36]$. As the expression level and activity of FoxO1 are significantly increased in the liver tissues of patients with severe fatty liver disease and type 2 diabetes mellitus, 
FoxO1 has an important role in the occurrence and progression of human metabolic syndrome [37-40]. Moreover, FoxO1 is located at the intersection of many signal transduction pathways and may become a target for the treatment or intervention of many diseases [36, 41, 42].

GSK-3 Glycogen synthase kinase-3 (GSK-3), an important molecule downstream of AKT, is a serine/threonine protease composed of an axis inhibition protein (Axin), $\beta$-catenin and adenomatous colonic polyposis protein $[43,44]$. Two GSK-3 subtypes exist: GSK-3alpha and GSK-3beta. The catalytically active regions of these two subtypes exhibit $97 \%$ sequence homology. Furthermore, GSK-3alpha and GSK-3beta are widely expressed in cells and tissues and have similar biological characteristics [45]. Recent studies have found that GSK-3beta can phosphorylate many endogenous substrates, including numerous proteins and transcription factors involved in metabolism. Therefore, GSK-3beta plays a crucial role in cell growth, development, tumorigenesis and blood sugar homeostatic regulation [43, 46, 47]. GSK-3 maintains the serine phosphorylation of IRS-1 in cells at rest and inhibits the activity of the protein. Additionally, Dokken et al. [48] reported that GSK-3 inhibits glycogen synthesis by phosphorylating glycogen synthase. Therefore, AKT can inhibit GSK-3 activity through phosphorylation an iny increasing glycogen synthase activity, promoting $\%$ cellular uptake and glycogen synthesis, and redu - ing b. $\mathrm{b}$ sugar levels. Furthermore, Lochhead et al. co 1 med tha GSK-3 affects the gene expression of PEPCK an $76 \mathrm{P}$ in the gluconeogenesis pathway [49]. GSK-3beta-kn, ckout mouse embryos reportedly die of h atic failure due to TNF-alpha toxicity on days 13.5-14.5 regrancy. However, GSK-3alpha cannot comp "ate for tnis defect, suggesting functional differences be tw. . he two GSK subtypes [50]. In pancreatic cells GSK-3beta knockdown demonstrated a prot ive foct on apoptosis induced by endoplasmic retic alum ess $[51,52]$. Moreover, GSK-3 participates in regulat $n$ of glycogen metabolism by mediating glyuoge nthesis, glucose transport, liver gluconeogeresis and bet, cell function [53, 54].

$m T \cap D \quad \mathrm{~m} \triangle \mathrm{P} /$ a serine/threonine protein kinase, is a em er of ne PI3K-associated kinase protein family th. Darmpates in sensing nutritional signals and regulatin. ell growth and proliferation [55]. mTOR includes mTOR complex 1 (mTORC1) and mTOR complex 2 (mTORC2). mTORC1, which is composed of mTOR, Raptor and mLST8, mainly regulates cell growth and energy metabolism and is sensitive to rapamycin. mTORC2, which is composed of mTOR, Rictor, Sin1 and mLST1, is mainly involved in reconstruction of the cytoskeleton and cell survival and is not sensitive to rapamycin $[56,57]$.
mTORC1 is a downstream molecule of AKT and is activated by phosphorylated AKT. As a PDK2, mTORC2 fully activates AKT by phosphorylating Ser473 [58]. The AKT/ TSC1-TSC2 signalling pathway can also regulate mTOR activity as well as cell growth and proliferation. TSC2 has GTPase activity and inhibits the small GTPase Rheb, which is necessary for mTORC1 activation [59]. Follewing phosphorylation of TSC2 by AKT, TSC2 loses its "1ty to inhibit mTORC1 and activate mTOR. In addition, $\square 2$ can be directly activated by AMPK phos, orylatitn, and AKT can completely inhibit TSC2 actur $1 \%$ OR by inhibiting AMPK [59, 60].

The downstream effectors of $n$ YR include two signalling pathways, namely, $\mathrm{TL}_{\mathrm{L}} \mathrm{1}$ a. oKs.MTOR may phosphorylate its dowrstream rget proteins 4EBPs, and eIF4E is a subun $\mathrm{C}$ - the euk, ryotic translation initiation complex [61]. Since vpophosphorylated 4E-BPs have a high affinls, for eIF,tE, phosphorylated 4E-BPs can be separau fr $\quad$ HE. The highly phosphorylated 4E-BP1 can relea eIF4E, which promotes the binding of eIF4G IF4E to initiate the translation of relevant mRNAs [62] su, dies have shown that 4E-BPs are major regulators of mTORC1 and affect mitochondrial biosyntII and function. In normal cells, inhibition of mTOR reduc $d$ the protein levels of ATP5O and TFAM and - $c$ ted the mitochondrial DNA content, mitochondrial mass and cellular ATP levels. In 4E-BP1/2-deficient cells, mTOR did not significantly inhibit ATP5O or TFAM, but the effects of mTOR inhibition on mitochondrial biosynthesis and ATP levels were attenuated.

S6Ks proteins are another target downstream of the mTOR pathway that are encoded by two cellular genes: S6K1 and S6K2 [63]. Many studies have shown that S6K1 can affect cell growth and proliferation by promoting the translation of related mRNAs. S6K1 can directly phosphorylate relevant components and factors associated with translation mechanism, such as ribosomal protein S6, eIF4B and PDCD4 [64]. Studies have shown that mTORC1 can activate SREBP1 through S6K1 [63]. Furthermore, overactivation of mTOR enhances lipid anabolism in mouse models of obesity and diabetes. Therefore, S6Ks are the main regulators of mTOR and affect cell lipid production [65].

\section{Pten}

The PI3K/AKT/mTOR signal transduction pathway is controlled by many factors. The tumour suppressor PTEN catalyses the reaction opposite of PIP3 generation by converting PIP3 to PIP2 [66, 67]. PTEN downregulates the $\mathrm{PI} 3 \mathrm{~K} / \mathrm{AKT} / \mathrm{mTOR}$ pathway to suppress cell proliferation and interfere with cellular metabolism, and inhibition of PTEN activity activates AKT and downstream pathways [68]. PTEN-knockout mice died during 
development due to the abnormal proliferation of various tissues. Furthermore, PIP3 levels were significantly higher in these tissues than in wild-type mice, and AKT was continuously activated [69]. Although PTEN-heterozygous mice survived, spontaneous tumours occurred. Furthermore, when PTEN was specifically knocked out in beta cells, the number and volume of these cells in mice increased significantly and induced hypoglycaemia $[70,71]$. In conclusion, studies have shown that PTEN plays an important role in regulating glucose homeostasis by modulating AKT activity.

\section{$\mathrm{PI} 3 \mathrm{~K} / \mathrm{AKT} / \mathrm{mTOR}$ inhibitors}

Many drugs targeting single PI3K, AKT or mTOR signalling proteins (single inhibitors) or targeting both PI3K and mTOR signalling proteins (dual inhibitors) have been developed and applied in preclinical studies and cancer clinical trials. Inhibitors targeting the PI3K/PI3K signalling pathway are hoped to improve the therapeutic effect of cancer treatment. Several inhibitors that have been studied more frequently are described below (Table 1).

\section{PI3K inhibitors}

LY294002 and wortmannin are well-studied first-generation pan-PI3K inhibitors [72]. LY294002 is a reversible
pan-PI3K inhibitor, and wortmannin is an irreversible pan-PI3K inhibitor. LY294002 is the first synthetic microparticle that can inhibit PI3K alpha/beta/gamma and hinder the formation of autophagosomes [73]. LY294002 sensitizes cancer cells to ionizing radiation by inactivating PKB, leading to cell cycle arrest. Because of its insolubility, short half-life, numerous nontarget eff cts and unacceptable toxic effects in animal studies, it. 'mical application is limited. A new generation of PI3K $\mathrm{h}$. tors (including BKM120, XL147, px-80 odc-0911 and gdc-0032) have been developed and chtero clin ical trials, and the representative drug $\&$ BKM120, 74$]$. NvpBKM120 (BKM120) has been sh in to actively inhibit cancer cell proliferation and 'ice, Losis in preclinical studies [75]. Phase I/rials $h_{h}$ shown that BKM120 is effective and well tor ted in patients with advanced cancer, and phase II and Ih als are still ongoing [75].

\section{AKT inhibitors}

Because AKT is a v transmitter of the PI3K/AKT signalling pa $\mathrm{N}, \mathrm{AK} / \mathrm{\Lambda}$ inhibitors have considerable prospects for th rgeto, cancer therapy. Here, two well-studied AKT inhibitors, Palomid529 (P529) and Pirifosine, are ma v introduced. Palomid529 (P529) is a novel and effect e AKT inhibitor that exhibits no toxicity in vivo

Table 1 PI3K, AKT, and mTOR inhibitors selected.A $\mathrm{pI}$ inicz,and clinical development(main PI3K/AKT/mTOR inhibitors in clinical trials) [73-81]

\begin{tabular}{|c|c|c|c|}
\hline Inhibitor & Compound or drug & Targets & Tu. types currently under investigation \\
\hline \multirow[t]{6}{*}{$\mathrm{PI3K}$} & LY294002 & Pan-class I I3K & Advanced solid tumors \\
\hline & Buparlisib (BKM120) & & Advanced solid tumors \\
\hline & SAR245408 (XL-147) & & Advanced solid tumors \\
\hline & Sonolisib (PX-866) & & $\begin{array}{l}\text { Phase II and III trials in NHL and CLL are underway, both alone and in combination with } \\
\text { hantiCD20 antibodies }\end{array}$ \\
\hline & & Ingha, Delta & $\begin{array}{l}\text { Added alpha specificity may provide benefit in MCLandsome others versus delta-only } \\
\text { inhibitors }\end{array}$ \\
\hline & & ha, Delta & Advanced solid tumors and metastatic breast cancer (ERp) \\
\hline \multirow[t]{7}{*}{ AKT } & & AKT & Advanced solid tumors, multiple myeloma \\
\hline & & AKT & $\begin{array}{l}\text { Advanced solid tumors, breast cancer, cervical cancer, endometrial cancer, leukemias, } \\
\text { melanoma, multiple myeloma }\end{array}$ \\
\hline & & AKT & $\begin{array}{l}\text { Advanced solid tumors, breast cancer, cervical cancer, endometrial cancer, leukemias, } \\
\text { melanoma, multiple myeloma }\end{array}$ \\
\hline & & AKT & $\begin{array}{l}\text { Advanced solid tumors, breast cancer, colorectal cancer, endometrial cancer, head \& neck } \\
\text { cancer, lung cancer, lymphomas, pancreatic cancer, prostate cancer }\end{array}$ \\
\hline & Everolimus(RAD001) & mTORC1 & $\begin{array}{l}\text { Approved for the treatment of renal cell carcinoma, subependymal giant cell astrocytoma } \\
\text { associated with tuberous sclerosis, pancreatic neuroendocrine tumors, and ERp breast } \\
\text { cancer }\end{array}$ \\
\hline & Temsirolimus & mTORC1 & Approved for the treatment of renal cell carcinoma \\
\hline & Rapamycin & mTORC 1 & Advanced solid tumors, multiple myeloma \\
\hline \multirow[t]{3}{*}{ Dual } & NVP-BEZ235 (BEZ-235) & P110, mTORC1/2 & Advanced solid tumors, multiple myeloma \\
\hline & SAR245409(XL765) & $\mathrm{PI} 3 \mathrm{~K} / \mathrm{mTOR}$ & $\begin{array}{l}\text { Advanced solid tumors, CLL, indolent non-Hodgkin lymphoma, mantle cell lymphoma, } \\
\text { ovarian cancer }\end{array}$ \\
\hline & GDC-0980 & $\mathrm{PI} 3 \mathrm{~K} / \mathrm{mTOR}$ & Solid cancers, non-Hodgkin lymphoma, breast cancer, prostate cancer \\
\hline
\end{tabular}


[76]. P529 combined with radiotherapy (RT) can reportedly improve the radiosensitivity of tumour cells and induce more apoptosis and DNA double-strand breaks (DSBs), leading to delayed tumour cell growth [76]. Pirifosine, an oral alkylphosphocholine analogue, is also an effective AKT inhibitor and has shown antitumour and radiosensitivity effects in preclinical studies. Studies have reported that Pirifosine enhances the radiosensitivity of cancer cells and inhibits the phosphorylation of AKT [77] These data provide strong support for the clinical application of AKT inhibitors.

\section{mTOR inhibitors}

MTOR is an established therapeutic target, and rapamycin is the representative mTOR inhibitor drug. Rapamycin (sirolimus), produced by Streptococcus, was initially used as an immunosuppressant to prevent organ transplant rejection [78]. Since elucidation of the important role of mTOR in tumorigenesis and progression, it is now being studied as a tumour suppressor. Rapamycin binds to the immunosuppressive protein fkbp-12 to form an immunosuppressive complex, inhibiting the transition of mTOR and G1 to S phase transition [79]. RAD001, also known as everolimus, is a novel rapamycin derivative similar to a mTOR inhibitor that inhibits mTORCi but has no effect on mTORC2 [80]. This drug is well/orerated and has strong antitumour properties, ind tir o its great prospects in cancer treatment. Rapar.ycin d RAD001, as well as other tacrolimus drugs seriou side effects, such as dyslipidaemia, pulmonar, oxicity and nephrotoxicity. Thus, the results of preclinica trials and early studies on mTOR inhibitor: re not ideal.

\section{Dual PI3K/AKT/mTOR inhibitors}

Short-term treatment with rapamy and its analogues was shown to inhibit ORC1 activity but triggered negative feedback to nhe AKT activation. On the other hand, $\mathrm{MTO}^{\text {r }}$ em. $\mathrm{s}$ activated in cancer cells even when the actiy of PI3, and AKT are inhibited [78]. These disturbance and feedback between mTOR and PI3K laro ely limit the,-nerapeutic efficacy of mTOR, AKT and Pro in ibilors. Therefore, dual PI3K/AKT/mTOR

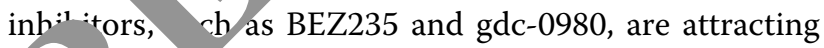
- cre , ing at ention from researchers. BEZ235 is the first a. rron mTOR inhibitor to enter clinical trials, the resu. of which show that the drug is well tolerated and has strong antitumour activity and is thus of substantial value for tumour treatment [81].

Studies on the PI3K/AKT signalling pathway as a targeted cancer therapy have been performed for more than a decade, and the Federal Drug Administration (FDA) has approved p110delta inhibitors for the treatment of certain types of lymphoma, providing hope for cancer treatment. A variety of PI3K/AKT signalling pathway inhibitors have been developed, but the drugs used in the clinic are limited due to the poor tolerance of patients and serious toxic side effects. Therefore, new PI3K/AKT/ mTOR signalling pathway inhibitors should be developed in the future that are more effective, less toxic and more tolerable to enhance the treatment of cancer pat ents.

\section{Roles of the PI3K/AKT/mTOR signalling patbway in neurodegenerative diseases and tumc. Progress in understanding the role of PISWAK, TOF, in $A D$} Alzheimer's disease(AD), the clir cal feature, of which include memory impairment, agn ia, visual-spatial skill impairment, executive dysfu ion, personality and behavioural changes, is the mos nportant neurodegenerative disease [82]. 11. neurop; hological features of AD include mainly neuron and synaptic damage [83]. The Tau protein $1 \mathrm{~S} G$ ential for microtubule assembly and structural intes vance, but abnormal Tau overphosphorylation a aggregation in AD lead to microtubule netw instab.iity and neurofibrillary tangle (NFT) formation, resur, ng in neuronal death and senile plaques [84].

T mediates Thr212 and Ser214 phosphorylation of th Tau protein, a process catalysed mainly by PI3KK2. Increased membrane levels of PIP3, the second messenger in the PI3K pathway, lead to colocalization of AKT and PDK1, which contains a PH domain, thus activating kinase-mediated phosphorylation [85]. Activated PI3K induces AKT activation and phosphorylates and inhibits GSK-3beta (GSK-3 is a multipotent serine/threonine protein kinase, and the GSK-3beta subtype has an important role in promoting Tau phosphorylation) [86]. Therefore, PI3K/AKT/mTOR signalling disorder can increase GSK-3beta activity and lead to Tau hyperphosphorylation, inducing NFT formation $[87,88]$. This finding also explains the observed PI3K/AKT/mTOR signal attenuation in the brains of $\mathrm{AD}$ patients.

The amyloid beta $(\mathrm{Ab})$ protein (the main component of precipitated plaques) also interacts with the PI3K/ AKT/mTOR pathway [89]. Abeta induces neurotoxicity by inhibiting the PI3K/AKT/mTOR pathway in neuronal cells and neural stem cells. GSK-3beta is mainly activated by Abeta oligomers, blocking PI3K/AKT/mTOR pathway activity, which increases Tau protein hyperphosphorylation [90].

\section{Progress in understanding the role of PI3K/AKT/mTOR in PD}

Parkinson's disease (PD), one of the most common neurodegenerative diseases, involves many motor symptoms (such as quiescent tremors, rigidity, and postural instability) and nonmotor symptoms (such as autonomic nervous, mental, sensory, and cognitive impairments) [82]. 
Despite the many studies on PD over the years, its pathogenesis remains unclear, and treatment remains difficult [91]. Studies have shown that AKT also plays a role in PD signal transduction. As serine/threonine-specific protein kinases, AKT and phosphorylated AKT are significantly reduced in the substantia nigra pars compacta $(\mathrm{SNpc})$ of PD patients [92]. PI3K/AKT/mTOR pathway activation also promotes the survival and growth of dopamine neurons by inhibiting apoptosis, thus preventing PD [93]. Experiments have shown that AKT can inhibit the activity of GSK-3 by phosphorylating Ser21 of GSK-3alpha or Ser9 of GSK-3beta. Moreover, abnormal regulation of GSK-3beta can lead to the pathophysiological manifestations of PD. Some studies have suggested that GSK-3beta is abnormally expressed in PD [94-96].

The PI3K/AKT/mTOR pathway affects the oxidative stress pathway through other downstream signalling molecules, such as FoxO3a, in addition to regulating GSK-3beta to influence PD. In the case of abnormal Parkin gene expression, oxidative stress becomes imbalanced primarily because the PI3K/AKT/FoxO3a pathway is disrupted, leading to $\mathrm{PD}$ [97]. The levels of mTOR, a downstream signalling molecule in the PI3K/AKT/mTOR pathway, were also found to be significantly reduced in the brain tissues of PD patients, although the PI3K/AKT/ mTOR pathway was found to have a protective effec on neurons [98]. Therefore, PI3K/AKT/mTOR affe P? largely by influencing downstream signalling nivlec s that regulate apoptosis.

The PI3K/AKT/mTOR signalling pathway a affect signal regulation in PD patients by nodulating, ownstream protein molecular targets, ch as GSK-3beta, mTOR and FoxO3a. Researchers have beçun to study potential drugs to treat PD, in ding sandroside (SAL), which can suppress GSK-3beta the PI3K/AKT/ mTOR pathway and thy luce 1 D symptoms [99].

\section{Research progress $M P I 3, \quad K T / m \Gamma O R$ in HD}

Early Huntingt disease $A D$ ) often manifests as irregular muscle twitc such as finger flexion and extension, nodaing and fac al muscle twitching. HD symptoms further v into sudden, purposeless and intense iny ntar darce-like movements of the face, neck, $1 \mathrm{mbs}$ and tr. nk, followed by corresponding psychiatric $s$ tom, such as depressive mood disorder and various degi of personality changes [100].

Inhibition of any part of the RAS/PI3K/AKT pathway significantly reduces the survival of cultured sympathetic neurons in the presence of nerve growth factor (NGF). As an upstream factor, RAS inhibits apoptosis through PI3K, indicating that the PI3K pathway is key for cell survival and neuron protection [101]. Brain-derived neurotrophic factor (BDNF), which regulates neurotransmitters, also plays an important role in the survival and growth of neurons, contributing to their plasticity, and is an indispensable cytokine for learning and memory. Some studies have shown that BDNF can bind to tropomyosin receptor kinase B (Trkb) and activate the PI3K/AKT pathway, thus protecting neurons and preventing HD develorment [102].

Furthermore, the Tau protein is substantiali, yperphosphorylated in HD neurons, serving as a pathor al manifestation of HD [103]. Studies have wn the GSK3beta, which is downstream of PI 1 AK is a crucial factor leading to Tau protein hyp rphosphor, /ation and is reversely regulated by the PI3K $\backslash$ KT pathway. Therefore, PI3K/AKT signalling ro ro Tau protein hyperphosphorylation through he downstream molecule GSK-3beta and $\mathrm{pa}_{\mathrm{a}}$ ipates $\mathrm{in}$ the occurrence and development of HD [104].

In summary th PI3K/AKT signalling pathway is involved in th oc ace and development of various neurodegene ive diseases, with important functions in $t$ noliferation of cells, inhibition of apoptosis and oxidat $\mathrm{Ve}$ St, $\mathrm{sS}$ and regulation of a variety of downstream molecules. The PI3K/AKT pathway is also assoCla with many other pathways. In general, the study of PI K/AKT pathway molecules and their interactions "provide new ideas for the mechanistic analysis of nearodegenerative diseases and corresponding drug development.

\section{Research progress on the PIIK/AKT/mTOR signalling pathway in cancer}

The occurrence and development of malignant tumours are the result of interactions between multiple signal transduction pathways. The $\mathrm{PI} 3 \mathrm{~K} / \mathrm{AKT} / \mathrm{mTOR}$ signal transduction pathway is abnormally activated in many tumorigenesis processes and has a key role in tumorigenesis and development. Furthermore, the PI3K/AKT/ mTOR pathway is involved in regulating the survival, proliferation, invasion and migration of cancer cells. Accordingly, inhibition of this pathway has become a hot research topic in cancer therapy.

Role in promoting tumorigenesis The PI3K/AKT/mTOR signalling pathway participates in cell cycle processes and promotes the occurrence and development of tumours. Many downstream molecules constitute the PI3K/AKT/ mTOR signalling pathway, such as mTOR, and activated AKT directly phosphorylates and thus activates mTOR. mTOR then promotes the binding of cyclin D1 to cyclindependent kinase (CDK) to initiate cell division. High levels of cyclin D1 expression can induce cell cycle transition from the G1 to $\mathrm{S}$ phase, shorten the cell cycle and accelerate cancer development. P27kip1 belongs to the CDK 
inhibitor protein family and negatively regulates the cell cycle; it inhibits the activity of CDK, leading to cell cycle arrest and blockage of cell proliferation. AKT inhibits the cell cycle blockade by phosphorylating P27kip1 and accelerates cell proliferation and differentiation [105]. Additionally, mTOR helps to regulate the synthesis of biological macromolecules such as proteins, nucleotides, and lipids, thus providing the materials necessary for cancer cell growth [106].

Role in controlling angiogenesis Angiogenesis is the basis of the growth, metastasis and lethality of tumours. The $\mathrm{PI} 3 \mathrm{~K} / \mathrm{AKT} / \mathrm{mTOR}$ signalling pathway is not only involved in regulating the proliferation and apoptosis of cancer cells but is also closely related to angiogenesis; moreover, the $\mathrm{PI} 3 \mathrm{~K} / \mathrm{AKT} / \mathrm{mTOR}$ pathway promotes normal and tumour angiogenesis [107]. Activated AKT causes eNOS distribution in the vascular endothelium by phosphorylating Ser1177, resulting in nitric oxide (NO) production in blood vessels. This phenomenon helps to regulate vascular function and causes vasodilation, vascular remodelling and angiogenesis [108]. In addition, AKT activation induces the expression of high levels of HIF-1, an important regulator of angiogenesis that can upregulate the expression of VEGF and other angiogenic factors, thereby promoting angiogenesis. HIF-1 affects vascular endo ntelial cells through the following mechanisms of act ${ }^{\prime}$ (') promoting the migration and proliferation of extoth al cells; (2) increasing vascular permeability, $\mathrm{pl}^{\mathrm{l}}$ a protel. exosmosis, and cellulose scaffold formation to he vascular endothelial cells migrate and provi a support ty $/ 2$ vascular growth; and (3) activating the roteolytic enzyme system, degrading the extracellular $\mathrm{m} \cdot \mathrm{v}$ and promoting angiogenesis [109-112].

Role in promoting car cell nvasion and metastasis The PI3K/AKT TC signalling pathway plays an important rol in $\mathrm{A}$ moting tumour invasion and metastasis via followi o mechanisms. (1) Activated AKT enhances th anscriptional activity of NF-kappa $B$, promses the tran port of tumours, and supports the invasio f . mo urs. (2) Actin polarization is promoted, and- KT , downstream molecule of PI3K, is reportAly volves, in regulating the invasion and metastasis o. easuancer cells. Palladin is an actin-related protein that ticipates in cytoskeleton construction, regulates the structure of the actin system and importantly functions in cell migration. AKT1 can phosphorylate Ser507 of palladin to regulate the invasion and metastasis of cancer cells [113]. (3) Activation of matrix metalloproteinases (MMPs), a group of proteolytic enzymes that participate in degrading the extracellular matrix, promotes cell invasion and metastasis. There are 23 types of MMPs, and MMP-2 and MMP-9 are known to be crucial for cell invasion. PI3K/AKT/mTOR can promote the expression of MMP-2 at the mRNA and protein levels, degrade the extracellular matrix, and promote the invasion and metastasis of cancer cells [106].

Based on the above findings, the PI3K/AKT/mTOR pathway plays an important role in tumoriger esis and development. When stimulated by upstrean. grals such as growth factors, PI3K activates AKT, whic ther activates downstream signalling olecul's and regulates cancer cell proliferation, :1rasio nd/metastasis, angiogenesis, and carb hydrate $\mathrm{n}$, etabolism. Accordingly, the growth and met tasis of tumours can be inhibited by suppressing exp on each molecule in the pathway ar a bloc signalling, resulting in an antitumour effec The deyelopment of targeted drugs following an in-de $\mathrm{r}_{\mathrm{H}}$ study of the PI3K/AKT/ mTOR signallig i thway is of great significance for cancer treatmo

\section{Perspecti $e$ s}

The PI3K/AKT/mTOR signalling pathway is an importan gnal transduction pathway that has many biological funct ns and is mediated by enzyme-linked receptors in - $m$.nals [114]. This pathway regulates biological activity by modulating the epigenetic modification of DNA and histones of target genes and plays important roles in cell differentiation, muscle development, environmental adaptation and disease development [2, 3, 115]. PI3K/ AKT/mTOR signalling components also phosphorylate and produce precursor apoptotic proteins, such as Bad. Short-term actions to prevent apoptotic pathway activation and ultimately lead to cell death have crucial roles in cell growth, proliferation and apoptosis and promote insulin-stimulated glucose uptake and storage. Overall, research on the biological activity of the PI3K-AKT pathway establishes an indispensable link between the growth and development of organisms and metabolism. PI3K/ $\mathrm{AKT} / \mathrm{mTOR}$ cascades in different cells produce different physiological and pathological effects that can lead to different pathophysiologies.

In conclusion, a thorough understanding of the key regulatory steps of the PI3K/AKT/mTOR pathway in various human diseases will help to elucidate the pathogenesis of cerebrovascular diseases, neurodegenerative diseases, diabetes mellitus and malignant tumours. More importantly, such research can provide new molecular targets (such as biological markers and genetic diagnoses) for the diagnosis and treatment of human diseases.

\section{Acknowledgements}

This manuscript was edited for proper English language, grammar, punctuation, spelling, and overall style by one or more of the highly qualified native 
English-speaking editors at American Journal Experts (certificate verification key: 3C15-D66C-5994-C6C8-4D1P).

\section{Authors' contributions}

Fei Xu and Lixin Na researched data for the article, Yanfei Li contributed to discussion of the content, and Fei Xu and Linjun Chen wrote, reviewed and edited the manuscript. All authors read and approved the final manuscript.

\section{Funding}

This project was supported by Grants from the National Science Foundation of China (number 8187120707), the Produce-Learn-Research Projects of Shanghai University of Medicine \& Health Sciences (number B1-0200-19311144) and the Online Course Construction Project of Shanghai University of Medicine \& Health Sciences (number B1-0200-19-309178).

\section{Availability of data and materials}

Not applicable.

\section{Ethics approval and consent to participate}

Not applicable.

\section{Informed consent}

Informed consent was obtained from all individual participants included in the study.

\section{Consent for publication}

Not applicable.

\section{Animals and human participants}

This article does not contain any studies involving animals or human participants that were performed by any of the authors.

\section{Competing interests}

The authors declare that they have no competing interests.

\section{Author details}

${ }^{1}$ Department of Microbiology and Immunology, Shanghai Unive ofy of cine \& Health Sciences, 279 Zhouzhu Rd, Shanghai 201318, Cb ${ }^{2}$ Collabo tive Innovation Center of Shanghai University of Medicine \& Hea Sciences, Shanghai 201318, China. ${ }^{3}$ Department of Inspection and Quaranti ' Changhai University of Medicine \& Health Sciences, Shangh ar 201318, China.y

Received: 14 November 2019 Accepted: 26 Mar 2020 Published online: 01 April 2020

\section{References}

1. Bilanges B, Posor Y, Va seb ack B. P, JK isoforms in cell signalling and vesicle trafficking. N. viviun ell Biol. 2019;20:515-34.

2. Jafari M, Ghada ij E, Dadkho Akhavan-Niaki H. PI3K/AKT signaling pathway: ery thesis and beyond. J Cell Physiol. 2019;234:2373-85.

3. Zhang M Znang $\lambda$ role of PIBK/AKT/FOXO signaling in psoriasis. Arch Dermatol Res. 2u \$11:83-91.

4. Yar $\mathrm{Q}$, Jing W Hou P. Emerging role of PI3K/AKT in tumor-related epig cregul tion. Semin Cancer Biol. 2019;59:112-24.

5 - anche 2 gri K, Flores-Leon M, Avila-Munoz E, Rodriguez-Corona Arias C. oK signaling in neurons: a central node for the control of Aw functions. Int J Mol Sci. 2018;19:E3725.

Very N, Vercoutter-Edouart AS, Lefebvre T, Hardiville S, El Yazidi-Belkoura Oss-dysregulation of O-GIcNAcylation and PI3K/AKT/mTOR axis in human chronic diseases. Front Endocrinol (Lausanne). 2018;9:602.

7. Nur Husna SM, Tan HT, Mohamud R, Dyhl-Polk A, Wong KK. Inhibitors targeting CDK4/6, PARP and PI3K in breast cancer: a review. Ther Adv Med Oncol. 2018;10:1758835918808509.

8. Matsuda S, Ikeda Y, Murakami M, Nakagawa Y, Tsuji A, Kitagishi Y. Roles of PI3K/AKT/GSK3 pathway involved in psychiatric illnesses. Diseases. 2019;7:E22.

9. Huang X, Liu G, Guo J, Su Z. The PI3K/AKT pathway in obesity and type 2 diabetes. Int J Biol Sci. 2018;14:1483-96.
10. Li YJ, Li XF, Yang EH, Shi M. Reaserch advances on the role of PI3K/AKT signaling pathway and MiRNA in acute T-cell lymphocytic leukemiareview. Zhongguo Shi Yan Xue Ye Xue Za Zhi. 2019;27:1344-7.

11. Rai SN, Dilnashin H, Birla H, Singh SS, Zahra W, Rathore AS, Singh BK, Singh SP. The Role of PI3K/Akt and ERK in neurodegenerative disorders. Neurotox Res. 2019;35:775-95.

12. Yudushkin I. Getting the Akt together: guiding intracellular Akt activity by PI3K. Biomolecules. 2019;9:E67.

13. Tsai CY, Dai KY, Fang C, Wu JCC, Chan SHH. PTEN/FU10540/P.3K/Akt cascade in experimental brain stem death: a newfound roler va ical tumorigenic signaling pathway. Biochem Pharmacol. 2018;15, 7-12

14. Presti D, Quaquarini E. The PI3K/AKT/mTOR and CDK4/6 Pathway Endocrine Resistant HR +/HER2-Metastatic Brea ancer: Bid'ogical Mechanisms and New Treatments. Cancers (B sel). P 11:E1 42.

15. Yu X, Long YC, Shen HM. Differential regu' atory functio fhree classes of phosphatidylinositol and pho hoinositide 3-knases in autophagy. Autophagy. 2015;11:17 11-2

16. Gyori D, Chessa T, Hawkins PT, St hens 4 oss (1) phosphoinositide 3-kinases in the tumor micro nviro ont. Cancers (Basel). 2017;9:E24.

17. Ghigo A, Morello F, Perino Hirsch E. cohoinositide 3-kinases in health and disease. Sub ct chem. 20, $2 ; 58: 183-213$.

18. Williams R, Berndt A, M. Uler S, WC, Zhang X. Form and flexibility in phosphoinositide inases. Bio in Soc Trans. 2009;37:615-26.

19. Bi L, Okabe I, P rnaro J, Nussbaum RL. Early embryonic lethality in mice deficien the catalytic subunit of PI 3-kinase. Mamm Genome. 2002; $9-72$.

20. Brachmann SM, Ue, Zngelman JA, Kahn RC, Cantley LC. Phosphoinositi ase caralytic subunit deletion and regulatory subunit deletiol have posite effects on insulin sensitivity in mice. Mol Cell Biol. 200. 25:1596-607.

Szymono ICz K, Oeck S, Malewicz NM, Jendrossek V. New insights to protein kinase B/Akt signaling: role of localized Akt activation d compartment-specific target proteins for the cellular radiation sponse. Cancers (Basel). 2018;10:E78.

Revathidevi S, Munirajan AK. Akt in cancer: mediator and more. Semin Cancer Biol. 2019;59:80-91.

23. Linton MF, Moslehi JJ, Babaev VR. Akt signaling in macrophage polarization, survival, and atherosclerosis. Int J Mol Sci. 2019;20:E2703.

24. Wadhwa B, Makhdoomi U, Vishwakarma R, Malik F. Protein kinase B: emerging mechanisms of isoform-specific regulation of cellular signaling in cancer. Anticancer Drugs. 2017;28:569-80.

25. Risso G, Blaustein M, Pozzi B, Mammi P, Srebrow A. Akt/PKB: one kinase, many modifications. Biochem J. 2015;468:203-14.

26. Simioni C, Martelli AM, Zauli G, Vitale M, McCubrey JA, Capitani S, Neri LM. Targeting the phosphatidylinositol 3-kinase/Akt/mechanistic target of rapamycin signaling pathway in B-lineage acute lymphoblastic leukemia: an update. J Cell Physiol. 2018;233:6440-54.

27. Tuncel G, Kalkan R. Receptor tyrosine kinase-Ras-PI 3 kinase-Akt signaling network in glioblastoma multiforme. Med Oncol. 2018;35:122.

28. Liu ST, Hui G, Mathis C, Chamie K, Pantuck AJ, Drakaki A. The current status and future role of the phosphoinositide 3 Kinase/AKT signaling pathway in urothelial cancer: an old pathway in the new immunotherapy era. Clin Genitourin Cancer. 2018;16:e269-76.

29. Kumar A, Rajendran V, Sethumadhavan R, Purohit R. AKT kinase pathway: a leading target in cancer research. Sci World J. 2013;2013:756134.

30. Hollenhorst PC, Bose ME, Mielke MR, Muller U, Fox CA. Forkhead genes in transcriptional silencing, cell morphology and the cell cycle. Overlapping and distinct functions for FKH1 and FKH2 in Saccharomyces cerevisiae. Genetics. 2000;154:1533-48.

31. Xing YQ, Li A, Yang Y, Li XX, Zhang LN, Guo HC. The regulation of FOXO1 and its role in disease progression. Life Sci. 2018;193:124-31.

32. Xu M, Chen X, Chen D, Yu B, Huang Z. FoxO1: a novel insight into its molecular mechanisms in the regulation of skeletal muscle differentiation and fiber type specification. Oncotarget. 2017:8:10662-74.

33. Cabrera-Ortega AA, Feinberg D, Liang Y, Rossa C Jr, Graves DT. The role of forkhead box 1 (FOXO1) in the immune system: dendritic cells, T cells, B cells, and hematopoietic stem cells. Crit Rev Immunol. 2017;37:1-13.

34. Tia N, Singh AK, Pandey P, Azad CS, Chaudhary P, Gambhir IS. Role of forkhead box O (FOXO) transcription factor in aging and diseases. Gene. 2018;648:97-105. 
35. Ma Z, Xin Z, Hu W, Jiang S, Yang Z, Yan X, Li X, Yang Y, Chen F. Forkhead box $O$ proteins: crucial regulators of cancer EMT. Semin Cancer Biol. 2018:50:21-31.

36. Maiese K. Forkhead transcription factors: formulating a FOXO target for cognitive loss. Curr Neurovasc Res. 2017;14:415-20.

37. Rajendran NK, Dhilip Kumar SS, Houreld NN, Abrahamse H. Understanding the perspectives of forkhead transcription factors in delayed wound healing. J Cell Commun Signal. 2019;13:151-62.

38. Gurnari C, Falconi G, De Bellis E, Voso MT, Fabiani E. The role of forkhead box proteins in acute myeloid leukemia. Cancers (Basel). 2019;11:E865.

39. Buteau J, Accili D. Regulation of pancreatic beta-cell function by the forkhead protein FoxO1. Diabetes Obes Metab. 2007;9(Suppl 2):140-6.

40. Xiao X, Chen C, Guo P, Zhang T, Fischbach S, Fusco J, Shiota C, Prasadan K, Dong H, Gittes GK. Forkhead box protein 1 (FoxO1) inhibits accelerated beta cell aging in pancreas-specific SMAD7 mutant mice. J Biol Chem. 2017;292:3456-65.

41. Wang J, Shen L, Hong H, Li J, Wang H, Li X. Atrasentan alleviates high glucose-induced podocyte injury by the microRNA-21/forkhead box O1 axis. Eur J Pharmacol. 2019;852:142-50.

42. Chen C, Luo Y, Su Y, Teng L. The vitamin D receptor (VDR) protects pancreatic beta cells against forkhead box class $\mathrm{O} 1$ (FOXO1)-induced mitochondrial dysfunction and cell apoptosis. Biomed Pharmacother. 2019;117:109170

43. Arioka M, Takahashi-Yanaga F. Glycogen synthase kinase-3 inhibitor as a multi-targeting anti-rheumatoid drug. Biochem Pharmacol. 2019;165:207-13.

44. Pandey MK, DeGrado TR. Glycogen synthase kinase-3 (GSK-3)-targeted therapy and imaging. Theranostics. 2016;6:571-93.

45. Liu X, Klein PS. Glycogen synthase kinase-3 and alternative splicing. Wiley Interdiscip Rev RNA. 2018;9:e1501.

46. Golpich M, Amini E, Hemmati F, Ibrahim NM, Rahmani B, Mohamed Z Raymond AA, Dargahi L, Ghasemi R, Ahmadiani A. Glycogen synthase kinase-3 beta (GSK-3beta) signaling: implications for Parkinson's disease. Pharmacol Res. 2015;97:16-26.

47. Mishra R. Glycogen synthase kinase 3 beta: can it be a target for ral cancer. Mol Cancer. 2010;9:144.

48. Dokken BB, Sloniger JA, Henriksen EJ. Acute selective glyce synthase kinase-3 inhibition enhances insulin signaling prediabet insulin-resistant rat skeletal muscle. Am J Physiol Enc'ocri Metab. 2005;288:E1188-94.

49. Lochhead PA, Coghlan M, Rice SQ, Sutherland R. Inhibition of C N-3 selectively reduces glucose-6-phosphatase id phosphatase and phosphoenolypyruvate carboxykinase gene pression. piabetes. 2001;50:937-46

50. Woodgett JR. Recent advances in th rotein kinase $B$ signaling pathway. Curr Opin Cell Biol. 2005;17:150

51. Han G, Casson RJ, Chidlow G. Wood JP, Th,e my,ochondrial complex I inhibitor rotenone induceso plasm reticulum stress and activation of GSK-3beta in cultur rat re hal cells/nvest Ophthalmol Vis Sci. 2014;55:5616-28.

52. Srinivasan S, Ob ugi M, Liu trai S, Bernal-Mizrachi E, Permutt MA. Endoplasmic tum stress, iduced apoptosis is partly mediated by reduced ins, lin sis "ing through phosphatidylinositol 3-kinase/Akt and in reased glycog oynthase kinase-3beta in mouse insulinoma cell biabetes. 2005;54:968-75.

53. Ma , an Ch $\cap$ Y, Zhang Y, Hou L, Cao X, Wang C. A polysaccharide from $\mathrm{G}$ fro dosa relieves insulin resistance of HepG2 cell by AktK-3 pat. ay. Glycoconj J. 2014;31:355-63.

LD. GSK-3 as a novel prognostic indicator in leukemia. Adv Biol Regur. 2017;65:26-35.

55. $X, X_{1} L$ Luo $L$, Chen J. Roles of mTOR signaling in tissue regeneration. Cells. 2019;8:E1075.

56. Murugan AK. mTOR: role in cancer, metastasis and drug resistance. Semin Cancer Biol. 2019;9:92-111.

57. Kim J, Guan KL. mTOR as a central hub of nutrient signalling and cell growth. Nat Cell Biol. 2019;21:63-71.

58. Khan MA, Jain VK, Rizwanullah M, Ahmad J, Jain K. PI3K/AKT/mTOR pathway inhibitors in triple-negative breast cancer: a review on drug discovery and future challenges. Drug Discov Today. 2019;24:2181-91.

59. Jhanwar-Uniyal M, Wainwright JV, Mohan AL, Tobias ME, Murali R, Gandhi CD, Schmidt MH. Diverse signaling mechanisms of mTOR complexes: mTORC1 and mTORC2 in forming a formidable relationship. Adv Biol Regul. 2019;72:51-62.

60. Karimi Roshan M, Soltani A, Soleimani A, Rezaie Kahkhaie K, Afshari AR, Soukhtanloo M. Role of AKT and mTOR signaling pathways in the induction of epithelial-mesenchymal transition (EMT) process. Biochimie. 2019;165:229-34.

61. Rivera-Calderon LG, Fonseca-Alves CE, Kobayashi PE, Carvalho M, Vasconcelos RO, Laufer-Amorim R. p-mTOR, p-4EBP-1 and elF4E ey ession in canine prostatic carcinoma. Res Vet Sci. 2019;122:86-92.

62. Mahoney RE, Azpurua J, Eaton BA. Insulin signaling contro transmission via the 4 eBP-dependent modification of the ex machinery. Elife. 2016;5:e16807. Yaguchi M, Ikeya S, Kozaki A. The activation mee $\mathrm{sm}$ of plat $\mathrm{t}$ So kinase (S6K), a substrate of TOR kinase, is diffe "nt th that of nammalian S6K. FEBS Lett. 2019. https://doi.o g/10.1002/10 +68.13661.

64. Na EJ, Nam HY, Park J, Chung MA, Woo H A, Kim HJ. PI3K-y, TTOR-S6K signaling mediates neuronal viability vi protein-2 expression. Front Moll roscl. 7.10.2.8.

65. Zhang Y, Zhang Y, Yu Y. Globahnhos, proteomic analysis of insulin/ Akt/mTORC1/S6K signalin in rat hepa vtes. J Proteome Res. 2017;16:2825-35.

66. Cretella D, Digiacomo , Gio etti E, Cavazzoni A. PTEN alterations as a potential mech - $n$ for tumo escape from PD-1/PD-L1 inhibition. Cancers ('asel). 19;11:E1318.

67. Luongo F, Co $\quad$ V Vitale S, Fiori ME, De Maria R. PTEN tumor-suppress he dam of stemness in cancer. Cancers (Basel). 2019, ${ }^{11} \cdot \mathrm{E} 1076$

68. Nader -ki AA, Rad JS, Ali-Hemmati A, Rahmati M, Charoudeh HN Reguro on and modulation of PTEN activity. Mol Biol Rep. 2018;45: 869-81.

Maehame P, Taylor GS, Dixon JE. PTEN and myotubularin: novel phos-

hoinositide phosphatases. Annu Rev Biochem. 2001;70:247-79.

70. les BL, Kuralwalla-Martinez C, Guo W, Gregorian C, Wang Y, Tian J, agnuson MA, Wu H. Selective deletion of Pten in pancreatic beta cells leads to increased islet mass and resistance to STZ-induced diabetes. Mol Cell Biol. 2006;26:2772-81.

71. Nguyen KT, Tajmir P, Lin CH, Liadis N, Zhu XD, Eweida M, Tolasa-Karaman G, Cai F, Wang R, Kitamura T, Belsham DD, Wheeler MB, Suzuki A, Mak TW, Woo M. Essential role of Pten in body size determination and pancreatic beta-cell homeostasis in vivo. Mol Cell Biol. 2006;26:4511-8.

72. Md Mokhtar AH, Malik IA, Abd Aziz NAA, Almabhouh FA, Durairajanayagam D, Singh HJ. LY294002, a PI3K pathway inhibitor, prevents leptin-induced adverse effects on spermatozoa in Sprague-Dawley rats. Andrologia. 2019;51:e13196.

73. Duarte A, Silveira GG, Soave DF, Costa JPO, Silva AR. The role of the LY294002 - a non-selective inhibitor of phosphatidylinositol 3-kinase (PI3K) pathway -in cell survival and proliferation in cell line SCC-25. Asian Pac J Cancer Prev. 2019;20:3377-83.

74. Bavelloni A, Focaccia E, Piazzi M, Orsini A, Ramazzotti G, Cocco L, Blalock W, Faenza I. Therapeutic potential of nvp-bkm120 in human osteosarcomas cells. J Cell Physiol. 2019;234:10907-17.

75. Hainsworth JD, Becker KP, Mekhail T, Chowdhary SA, Eakle JF, Wright D, Langdon RM, Yost KJ, Padula GDA, West-Osterfield K, Scarberry M, Shaifer CA, Shastry M, Burris HA 3rd, Shih K. Phase I/II study of bevacizumab with BKM120, an oral PI3K inhibitor, in patients with refractory solid tumors (phase I) and relapsed/refractory glioblastoma (phase II). J Neurooncol. 2019;144:303-11.

76. Weinberg MA. RES-529: a PI3K/AKT/mTOR pathway inhibitor that dissociates the mTORC1 and mTORC2 complexes. Anticancer Drugs. 2016;27:475-87.

77. Kaley TJ, Panageas KS, Mellinghoff IK, Nolan C, Gavrilovic IT, DeAngelis LM, Abrey LE, Holland EC, Lassman AB. Phase II trial of an AKT inhibitor (perifosine) for recurrent glioblastoma. J Neurooncol. 2019;144:403-7.

78. Peng K, Fan X, Li Q, Wang Y, Chen X, Xiao P, Passerini AG, Simon SI, Sun C. IRF-1 mediates the suppressive effects of mTOR inhibition on arterial endothelium. J Mol Cell Cardiol. 2020. https://doi.org/10.1016/j.yjmcc .2020.02.006

79. Mendez-Gomez M, Castro-Mercado E, Pena-Uribe CA, Reyes-de la Cruz H, Lopez-Bucio J, Garcia-Pineda E. TARGET OF RAPAMYCIN signaling plays a role in Arabidopsis growth promotion by Azospirillum brasilense Sp245. Plant Sci. 2020;293:110416. 
80. Brakemeier S, Arns W, Lehner F, Witzke O, Vonend O, Sommerer C, Muhlfeld A, Rath T, Schuhmann R, Zukunft B, Kroeger I, Porstner $\mathrm{M}$, Budde K. Everolimus in de novo kidney transplant recipients participating in the Eurotransplant senior program: results of a prospective randomized multicenter study (SENATOR). PLoS ONE. 2019;14:e0222730.

81. Schotz U, Balzer V, Brandt FW, Ziemann F, Subtil FSB, Rieckmann T, Kocher S, Engenhart-Cabillic R, Dikomey E, Wittig A, Arenz A. Dual PI3K/mTOR inhibitor NVP-BEZ235 enhances radiosensitivity of head and neck squamous cell carcinoma (HNSCC) cell lines due to suppressed double-strand break (DSB) repair by non-homologous end joining. Cancers (Basel). 2020. https://doi.org/10.3390/cancers120 20467.

82. Martins AC Jr, Morcillo P, ljomone OM, Venkataramani V, Harrison FE, Lee $E$, Bowman AB, Aschner M. New insights on the role of manganese in Alzheimer's Disease and Parkinson's Disease. Int J Environ Res Public Health. 2019;16:E3546.

83. Affoo RH, Foley N, Rosenbek J, Shoemaker JK, Martin RE. Swallowing dysfunction and autonomic nervous system dysfunction in Alzheimer's disease: a scoping review of the evidence. J Am Geriatr Soc. 2013;61:2203-13.

84. Caricasole A, Copani A, Caruso A, Caraci F, lacovelli L, Sortino MA, Terstappen GC, Nicoletti F. The Wnt pathway, cell-cycle activation and beta-amyloid: novel therapeutic strategies in Alzheimer's disease? Trends Pharmacol Sci. 2003;24:233-8.

85. Howes AL, Arthur JF, Zhang T, Miyamoto S, Adams JW, Dorn GW 2nd, Woodcock EA, Brown JH. Akt-mediated cardiomyocyte survival pathways are compromised by $\mathrm{G}$ alpha q-induced phosphoinositide 4,5-bisphosphate depletion. J Biol Chem. 2003;278:40343-51.

86. Ksiezak-Reding H, Pyo HK, Feinstein B, Pasinetti GM. Akt/PKB kinase phosphorylates separately Thr212 and Ser214 of tau protein in vitro. Biochim Biophys Acta. 2003;1639:159-68.

87. Lee CW, Lau KF, Miller CC, Shaw PC. Glycogen synthase kinase-3 betamediated tau phosphorylation in cultured cell lines. NeuroReport 2003;14:257-60.

88. Wen Y, Planel E, Herman M, Figueroa HY, Wang L, Liu L, Lau K Duff KE. Interplay between cyclin-dependent kinase 5 ar alyc synthase kinase 3 beta mediated by neuregulin signa $q$ leads to differential effects on tau phosphorylation and am roia cursor ) protein processing. J Neurosci. 2008;28:2624-32

89. Do TD, Economou NJ, Chamas A, Buratto SK shea JE, Bowers $1 T$. Interactions between amyloid-beta and $\mathrm{Ta}$ fragments promote aberrant aggregates: implications for amyl toxicity. Phys Chem B. 2014;118:11220-30.

90. Kitagishi Y, Nakanishi A, Ogura Y, Mi uda S. Dietary regulation of PI3K/AKT/GSK-3beta pathway in Alż Ir dicease. Alzheimers Res Ther. 2014;6:35.

91. Carrarini C, Russo M, Donon Pietro M, Rispoli MG, Di Stefano V, Ferri L, Barbone F, Vit - M, Tr mas A, ensi SL, Onofrj M, Bonanni L. A stage-based apprazch. etap, Parkinson's Disease. Biomolecules. 2019. ht os://doi.on 0.3390/biom9080388.

92. Luo S, Kang Ss, ng ZH, Liu , Day JX, Wu Z, Peng J, Xiang D, Springer W, Ye K. Dhosphorylates NQO1 and triggers its degradation, a onshing its al Kidative activities in Parkinson's Disease. J Nel osci. 2019;39:7291-305.

93. Leik W wubta S, Theilmann W, Jalkanen AJ, Forsberg MM, Rantamak ief oflurane anesthesia regulates striatal AKT-GSK3beta naling a ameliorates motor deficits in a rat model of early-stage 4.incon's disease. J Neurochem. 2017;142:456-63. Jia Y, Ivro SJ, Feng QQ, Zhan ML, OuYang LS, Chen JC, Ma YX, Wu JJ, Lei EPO-dependent activation of PI3K/Akt/FoxO3a signalling mediares neuroprotection in in vitro and in vivo models of Parkinson's disease. J Mol Neurosci. 2014;53:117-24.

95. Yang L, Wang H, Liu L, Xie A. The role of insulin/IGF-1/PI3K/Akt/ GSK3beta signaling in Parkinson's disease dementia. Front Neurosci. 2018;12:73.

96. Zhang W, He H, Song H, Zhao J, Li T, Wu L, Zhang X, Chen J. Neuroprotective effects of salidroside in the MPTP mouse model of Parkinson's disease: involvement of the PI3K/Akt/GSK3beta pathway. Parkinsons Dis. 2016;2016:9450137.
97. Gong J, Zhang L, Zhang Q, Li X, Xia XJ, Liu YY, Yang QS. Lentiviral vector-mediated $S H C 3$ silencing exacerbates oxidative stress injury in nigral dopamine neurons by regulating the PI3K-AKT-FoxO signaling pathway in rats with Parkinson's disease. Cell Physiol Biochem. 2018:49:971-84.

98. Giacoppo S, Bramanti P, Mazzon E. Triggering of inflammasome by impaired autophagy in response to acute experimental Parkinson's disease: involvement of the PI3K/Akt/mTOR pathway. Neurop port. 2017:28:996-1007.

99. Chen WF, Wu L, Du ZR, Chen L, Xu AL, Chen XH, Teng J J Neuroprotective properties of icariin in MPTP-induced mot of Parkinson's disease: involvement of PI3K/Akt aríd MEK/ERK ing pathways. Phytomedicine. 2017;25:93-9.

100. Ribeiro M, Rosenstock TR, Oliveira AM, Olive ' $\mathrm{C} C \mathrm{C}$ and IGF-1 improve mitochondrial function in a PI-3K aependent manner and reduce mitochondrial ge ration of react,ve oxygen species in Huntington's disease knock striatal ce ls. Free Radic Biol Med. 2014;74:129-44.

101. Vaillant AR, Mazzoni I, Tudan C, Ba vau M, Kaplan DR, Miller FD. Depolarization and neurc rophins co roe on the phosphatidylinositol 3-kinase-Ak $\mathrm{A}$. way to syn-rgistically regulate neuronal survival. J Cell Biol. 19, $9 ; 140-66$.

102. Silva $A$, Naia $L, D$ nguez $A$, h í M, Rodrigues J, Vieira OV, Lessmann V, P ego A Overexpression of BDNF and full-length TrkB receptor ano reural survival in Huntington's disease. Neurodegener $2015 ; 15: 207-18$.

103. Ferna dez-Nogale Cabrera JR, Santos-Galindo M, Hoozemans JJ, Ferrer muller AJ, Hernandez F, Avila J, Lucas JJ. Huntington's disease is 100 , epeat tauopathy with tau nuclear rods. Nat Med. 2014;20: 81-5.

L'Episcop 4, Drouin-Ouellet J, Tirolo C, Pulvirenti A, Giugno R, Testa Caniglia S, Serapide MF, Cisbani G, Barker RA, Cicchetti F, Marchetti GSK-3beta-induced Tau pathology drives hippocampal neuronal Il death in Huntington's disease: involvement of astrocyte-neuron Interactions. Cell Death Dis. 2016;7:e2206.

Riquelme I, Tapia O, Espinoza JA, Leal P, Buchegger K, Sandoval A, Bizama C, Araya JC, Peek RM, Roa JC. The gene expression status of the PI3K/AKT/mTOR pathway in gastric cancer tissues and cell lines. Pathol Oncol Res. 2016;22:797-805.

106. Cheng TC, Din ZH, Su JH, Wu YJ, Liu Cl. Sinulariolide suppresses cell migration and invasion by inhibiting matrix metalloproteinase-2/-9 and urokinase through the PI3K/AKT/mTOR signaling pathway in human bladder cancer cells. Mar Drugs. 2017. https://doi. org/10.3390/md15080238.

107. Zhou Y, Li S, Li J, Wang D, Li Q. Effect of microRNA-135a on cell proliferation, migration, invasion, apoptosis and tumor angiogenesis through the IGF-1/PI3K/Akt signaling pathway in non-small cell lung cancer. Cell Physiol Biochem. 2017:42:1431-46.

108. Chang CZ, Wu SC, Chang CM, Lin CL, Kwan AL. Arctigenin, a potent ingredient of Arctium lappa $\mathrm{L}$., induces endothelial nitric oxide synthase and attenuates subarachnoid hemorrhage-induced vasospasm through PI3K/Akt pathway in a rat model. Biomed Res Int. 2015:2015:490209.

109. Tsubaki M, Takeda T, Tomonari Y, Koumoto Yl, Imano M, Satou T, Nishida S. Overexpression of HIF-1alpha contributes to melphalan resistance in multiple myeloma cells by activation of ERK1/2, Akt, and NF-kappaB. Lab Invest. 2019;99:72-84.

110. Patra K, Jana S, Sarkar A, Mandal DP, Bhattacharjee S. The inhibition of hypoxia-induced angiogenesis and metastasis by cinnamaldehyde is mediated by decreasing HIF-1alpha protein synthesis via PI3K/Akt pathway. BioFactors. 2019:45:401-15.

111. Zhang J, XU J, Dong Y, Huang B. Down-regulation of HIF-1alpha inhibits the proliferation, migration, and invasion of gastric cancer by inhibiting PI3K/AKT pathway and VEGF expression. Biosci Rep. 2018. https://doi.org/10.1155/2015/490209.

112. Wei Y, Hong H, Zhang X, Lai W, Wang Y, Chu K, Brown J, Hong G, Chen L. Salidroside inhibits inflammation through PI3K/Akt/HIF signaling after focal cerebral ischemia in rats. Inflammation. 2017;40:1297-309.

113. Chin YR, Toker A. The actin-bundling protein palladin is an Akt1-specific substrate that regulates breast cancer cell migration. Mol Cell. 2010:38:333-44. 
114. Castellino RC, Durden DL. Mechanisms of disease: the PI3K-Akt-PTEN signaling node-an intercept point for the control of angiogenesis in brain tumors. Nat Clin Pract Neurol. 2007;3:682-93.

115. Abraham J. PI3K/AKT/mTOR pathway inhibitors: the ideal combination partners for breast cancer therapies? Expert Rev Anticancer Ther. 2015;15:51-68.

\section{Publisher's Note}

Springer Nature remains neutral with regard to jurisdictional claims in published maps and institutional affiliations.

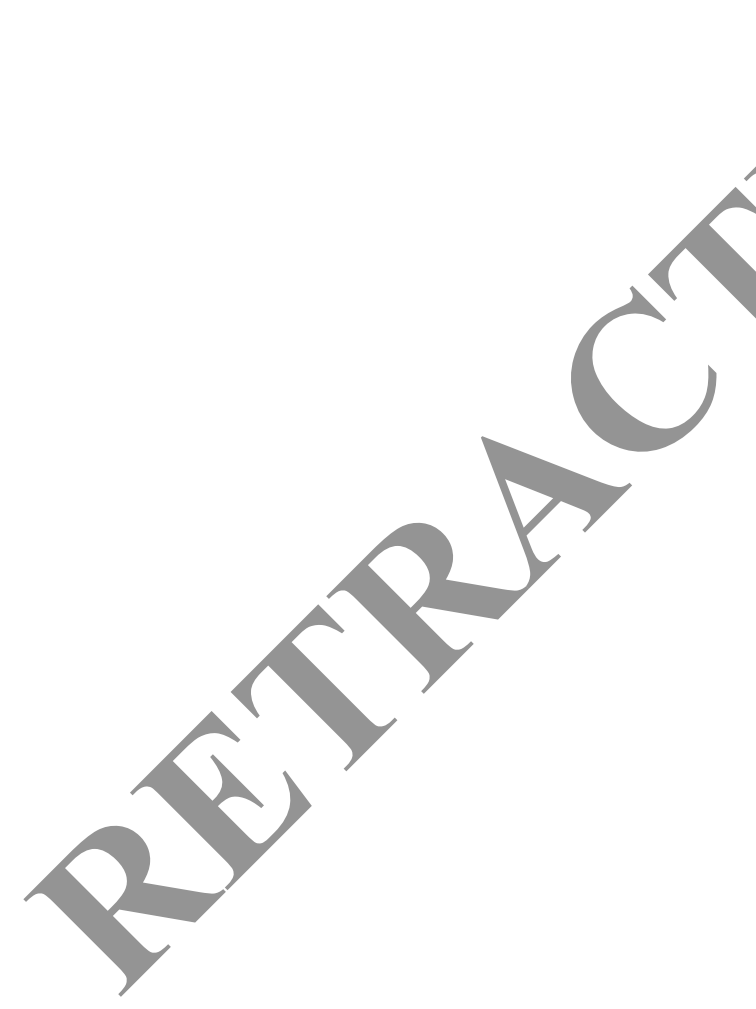

Ready to submit your research? Choose BMC and benefit from:

- fast, convenient online submission

- thorough peer review by experienced researchers in your field

- rapid publication on acceptance

- support for research data, including large and complex data types

- gold Open Access which fosters wider collaboration and increased citations

- maximum visibility for your research: over 100M website views per year

At BMC, research is always in progress.

Learn more biomedcentral.com/submissions 